Creative commons User License: CC BY-NC-ND

Abstracted by: EBSCOhost, Electronic Journals Service (EJS), Google Scholar, Directory of Open Access Journals (DOAJ), Journal Seek, Scientific Commons,

Food and Agricultural Organization (FAO), CABI and Scopus
Journal of Agricultural Extension

Vol. 21 (1) February, 2017

ISSN(e): 24086851; ISSN(Print); 1119944X

http://journal.aesonnigeria.org

http://www.ajol.info/index.php/jae

Email: editorinchief@aesonnigeria.org

\title{
Farmers Adoption Scenarios for the Control of Cassava Mosaic Disease under the Cassava Enterprise Development Project in Enugu State, Nigeria
}

http://dx.doi.org/10.4314/jae.v21i1.15

\author{
Agwu, A. E. \\ Department of Agricultural Extension, Faculty of Agriculture \\ University of Nigeria, Nsukka \\ Email: ekwe.agwu@unn.edu.ng \\ $+2348034024251$
}

Njom, P. C.

Project Monitoring and Evaluation Unit,

Enugu State Agricultural Development Programme (ENADEP) Enugu State, Nigeria

Email: njomp@yahoo.com

$+2348064946041$

\author{
Umeh, B. U. \\ Department of Agricultural Extension, Faculty of Agriculture \\ University of Nigeria, Nsukka \\ Email: bravo.umeh@unn.edu.ng \\ $+2348034077005$
}

\begin{abstract}
This study determined farmers' adoption levels of the cassava varieties and value adding technologies introduced under the project. Data for the study were collected from 260 randomly selected respondents using interview schedule. Farmers' adoption indices were used to summarize information on adoption levels, while exploratory factor analysis procedure using principal factor model with varimax rotation was used in grouping the major constraint factors to adoption. Results showed that farmers were still at the interest stage of the adoption of the cassava mosaic disease (CMD) resistant varieties $(\bar{x}=2.44)$, cassava processing innovations $(\bar{x}=2.32)$, and improved marketing methods $(\bar{x}=2.25)$. Farmers were at the evaluation stage in the adoption of agronomic practices $(\bar{x}=3.27)$ while, processors were at the evaluation stage in both processing and improved marketing innovations $(\bar{x}=3.43$ and 3.12 respectively). However, they were at interest stage $(\bar{x}=2.84)$ in the adoption of the value adding technologies. Public and private extension agencies should therefore be encouraged to continue the extension service delivery of the CEDP innovations for greater proportion of cassava farmers to adopt the new varieties for sustainable production of cassava in the country.
\end{abstract}

Keywords: Improved cassava variety, Cassava mosaic disease, Cassava enterprise development project 
Creative commons User License: CC BY-NC-ND

Abstracted by: EBSCOhost, Electronic Journals Service (EJS), Google Scholar, Directory of Open Access Journals (DOAJ), Journal Seek, Scientific Commons,

Food and Agricultural Organization (FAO), CABI and Scopus
Journal of Agricultural Extension

Vol. 21 (1) February, 2017

ISSN(e): 24086851; ISSN(Print); 1119944X

http://journal.aesonnigeria.org

http://www.ajol.info/index.php/jae

Email: editorinchief@aesonnigeria.org

\section{Introduction}

The relevance of cassava particularly to the rural economy is shown in every aspect of the crop, from the leaves through the stem down to the root which has industrial relevance both locally and for the international market. The economic importance and industrial relevance of cassava crop as both food and non-food product has been illustrated (Erhabor and Emokano, 2007). The potential of cassava remained unexplored until when the federal government launched the presidential initiative on cassava in 2002 (Adetunji, 2007). The intent of the initiative is to use cassava as the engine of growth in Nigeria. Adetunji (2007) further noted that, if investments in the downstream sector of the cassava industry is made more effective, cassava can be used to improve rural and urban income and employment in the country. Also, under this initiative, the industrial uses of cassava and its export potential as a foreign exchange earner were highlighted and brought to lime light. These advances made by Nigeria in cassava production became threatened in 2002 by a virulent form of the cassava mosaic disease advancing rapidly from Uganda East Africa (Sanni, Ezedinma, Okechukwu, Lemchi, 2007). The disease is said to be capable of wiping out the cassava crop in Nigeria and West Africa.

To counter this threat and working in tandem with the global and national efforts on food security, the United States Agency for International Development (USAID), in collaboration with Shell Petroleum Development Company (SPDC) and the International Institute of Tropical Agriculture (IITA) initiated \$11.7 million Cassava Enterprise Development Project (CEDP) with its complementary project of preemptive management of the cassava mosaic disease in the eleven cassava growing states of the South-south and South east, Nigeria (Tarawali, Ayoola, Ezedinma, Okechukwu, et. al., 2007).

The project has three core components which include the reduction of the impact of virulent cassava mosaic disease in the south-east and south-south agro-ecological zones of Nigeria. The CEDP aims to stem the disease through the wide spread dissemination and adoption of high yielding, disease resistant cassava varieties. The second is to increase cassava productivity. The CEDP aimed at doing this through generation, promotion and adoption of demand-driven, sustainable and competitive 
Creative commons User License: CC BY-NC-ND

Abstracted by: EBSCOhost, Electronic Journals Service (EJS), Google Scholar, Directory of Open Access Journals (DOAJ), Journal Seek, Scientific Commons,

Food and Agricultural Organization (FAO), CABI and Scopus
Journal of Agricultural Extension

Vol. 21 (1) February, 2017

ISSN(e): 24086851; ISSN(Print); 1119944X

http://journal.aesonnigeria.org

http://www.ajol.info/index.php/jae

Email: editorinchief@aesonnigeria.org

cassava production technologies. The third component is the development and expansion of postharvest processing and marketing outlets for cassava products. The project aims to achieve this through strengthening small and medium scale processors and enterprises and facilitate their access to post harvest processing technologies, credit, information and domestic markets.

The CEDP commenced operation in Enugu state in 2003/2004 cropping season. Three hundred and eighty-one (381) recipient cassava farmers were selected throughout the major cassava producing local governments of the state based on their experience in cassava production and availability of prepared land for the cassava varieties. Multi-locational trials (MLTs) were conducted by the scientists to identify specific and broadly adapted CMD resistant genotypes with end-users characteristics and also on farm trials (OFTs) were established in collaboration with farmers to identify CMD resistant genotypes that are adapted to their agronomic and cultural practices and high economic returns in terms of high roots yield and root quality characteristics for easy adoption of the cassava varieties.

The project's life-span came to end in 2009. The pertinent questions to ask include: Did the farmers adopt the improved cassava varieties and the value-adding technologies introduced through CEDP extension activities? What are the perceived factors militating against adoption of the improved cassava varieties and value adding technologies by the farmers? This study therefore sought to provide answers to these questions

\section{Purpose of the Study}

The purpose of the study was to determine the farmers' adoption scenarios under the Cassava Enterprise Development Project in Enugu State, Nigeria. Specifically, the study was designed to:

i. determine the adoption levels of the cassava varieties and value adding technologies introduced to the farmers; and

ii. Ascertain the constraints to effective adoption of the innovations by the farmers; 
Creative commons User License: CC BY-NC-ND

Abstracted by: EBSCOhost, Electronic Journals Service (EJS), Google Scholar, Directory of Open Access Journals (DOAJ), Journal Seek, Scientific Commons,

Food and Agricultural Organization (FAO), CABI and Scopus
Journal of Agricultural Extension

Vol. 21 (1) February, 2017

ISSN(e): 24086851; ISSN(Print); 1119944X

http://journal.aesonnigeria.org

http://www.ajol.info/index.php/jae

Email: editorinchief@aesonnigeria.org

\section{Methodology}

The study was carried out in Enugu State, Nigeria. The state is located between $5^{\circ} 56^{\prime} \mathrm{N}$ and $7^{\circ} 06^{\prime} \mathrm{N}$ and longitude $6^{\circ} 53 \mathrm{E}$ and $7^{\circ} 55^{\prime} \mathrm{E}$. The state is bounded on the north-east by Ebonyi state, on the north by Benue and Kogi States, on the south by Abia State, on the east by Cross-River and on the west by Anambra State. It occupies an area of about $8,022.95 \mathrm{KM}^{2}$ (Ezike, 1998) and has a population of about $3,257,278$ persons (NPC, 2006).

The population involved in cassava production in the state was 246,542 farm families who cultivated 229, 300 hectares by 2006 (NFRA, 2007). All cassava farmers in Enugu State (CEDP and non- project farmers) and extension staff of ADP constituted the population for the study. A multistage sampling technique was used in the selections of the respondents. All the ten LGAs (Uzo-Uwani, Nsukka, Awgu, Aninri, Oji-river, Igbo-Etiti, Udi, Ezeagu, Enugu East and Enugu South) that participated in the CEDP were purposively selected for the study. From each of the 10 LGAs, 10 CEDP cassava farmers were selected from the 381 farmers that participated in the project using simple random sampling technique. In all a total of 100 participating cassava farmers were sampled.

Equal number of non- CEDP cassava processors, were purposively selected from the above listed LGAs (Table 1). The non-CEDP cassava farmers and processors served as a comparison group to estimate the impact of the project on the participating farmers and processors. Also, 20 staff of the Agricultural Development Programme (ADP) who participated in the project were purposively selected for the study. In all, 260 respondents made up of 100 CEDP farmers and non CEDP farmers as well as 20 CEDP processors and non CEDP processors respectively and 20 extension agents constituted the sample size for the study. 
Creative commons User License: CC BY-NC-ND

Abstracted by: EBSCOhost, Electronic Journals Service (EJS), Google Scholar, Directory of Open Access Journals (DOAJ), Journal Seek, Scientific Commons,

Food and Agricultural Organization (FAO), CABI and Scopus
Journal of Agricultural Extension

Vol. 21 (1) February, 2017

ISSN(e): 24086851; ISSN(Print); 1119944X

http://journal.aesonnigeria.org

http://www.ajol.info/index.php/jae

Email: editorinchief@aesonnigeria.org

Table 1: Population and sampling procedure

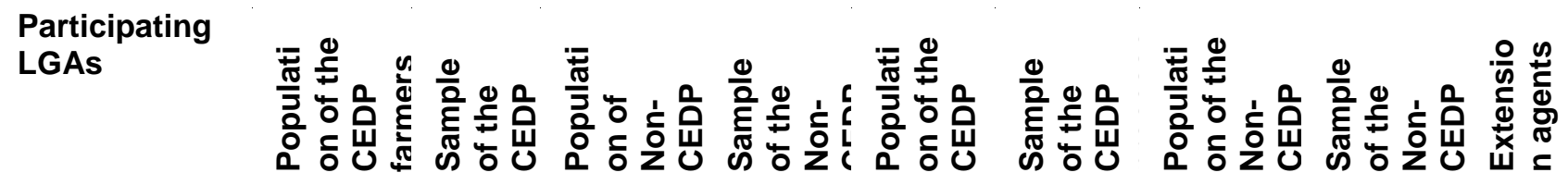

\begin{tabular}{llllllllll}
\hline Uzo- Uwani & 36 & 10 & 20 & 10 & 2 & 2 & 14 & 2 & 2 \\
Nsukka & 58 & 10 & 20 & 10 & 3 & 3 & 11 & 3 & 2 \\
Awgu & 23 & 10 & 20 & 10 & 2 & 2 & 9 & 2 & 2 \\
Aninri & 22 & 10 & 20 & 10 & 1 & 1 & 19 & 1 & 2 \\
Oji-river & 36 & 10 & 20 & 10 & 2 & 2 & 8 & 2 & 2 \\
Igbo -Etiti & 46 & 10 & 20 & 10 & 1 & 1 & 13 & 1 & 2 \\
Udi & 36 & 10 & 20 & 10 & 2 & 2 & 8 & 2 & 2 \\
Ezeagu & 41 & 10 & 20 & 10 & 2 & 2 & 15 & 2 & 2 \\
Enugu - east & 43 & 10 & 20 & 10 & 4 & 4 & 11 & 4 & 2 \\
Enugu south & 40 & 10 & 20 & 10 & 1 & 1 & 6 & 1 & 2 \\
\hline Total & $\mathbf{3 8 1}$ & $\mathbf{1 0 0}$ & & $\mathbf{1 0 0}$ & & $\mathbf{2 0}$ & $\mathbf{1 1 4}$ & $\mathbf{2 0}$ & $\mathbf{2 0}$ \\
\hline
\end{tabular}

\section{Instrument for data collection}

Data for this study were collected using interview schedule (for the farmers and processors) and questionnaire (for extension agents). To determine the adoption level of the cassava varieties and the value adding technologies introduced to the farmers (objective 1), a 5-point Likert-type adoption scale was used. For each of the technologies itemized in the interview schedules, the farmers were asked to indicate their adoption state on the 5-point adoption scale. Their response categories and the corresponding weighted value were awareness $=1$, interest $=2$, evaluation $=3$, trial $=4$ and adoption $=5$. The adoption indices of the farmers were calculated as follows:

a. total mean $(\bar{x})$ adoption score. This was computed by dividing the total adoption scores by the number of respondents involved.

b. grand mean $(\bar{x})$ adoption score. This was calculated by adding all the mean adoption scores and dividing them by the number of innovations considered.

c. adoption index was carried out by dividing the grand mean $(\vec{x})$ adoption score by 5 .

To ascertain the constraints to effective adoption of the innovation by the farmer, a list of possible constraints was made available. Farmers were asked to indicate the level of their perceived seriousness of each constraints on a 4-point response scale ( $4=$ to a great extent; $3=$ to some extent; $2=$ to a little extent; $1=$ No extent). Data were 
Creative commons User License: CC BY-NC-ND

Abstracted by: EBSCOhost, Electronic Journals Service (EJS), Google Scholar, Directory of Open Access Journals (DOAJ), Journal Seek, Scientific Commons,

Food and Agricultural Organization (FAO), CABI and Scopus
Journal of Agricultural Extension

Vol. 21 (1) February, 2017

ISSN(e): 24086851; ISSN(Print); 1119944X

http://journal.aesonnigeria.org

http://www.ajol.info/index.php/jae

Email: editorinchief@aesonnigeria.org

subjected to exploratory factor analysis procedure using principal factor model with varimax rotation in grouping the constraint variables into major constraint factors.

\section{Results and Discussion}

\section{Socio-economic Characteristics of Respondents}

The processors as well as the non-participant farmers and non-CEDP processors were above 40 years indicating that youths are no more attracted to cassava farming and processing. There is need therefore to encourage the youth involvement in cassava business enterprises by governments and other stakeholders in agriculture. According to Ezedinma, Lemchi, Okechukwu, Ogbe, et. al., (2007) cassava product enterprises are considered unattractive by the youth as it involves hard physical work and poor wage. The majority (53. 6\%) of participant farmers were male while $46.4 \%$ were females. Also, the majority (52.9\%) of the non-participant farmers were males, while $47 \%$ were females. The table also indicates that the majority $(65 \%)$ of the CEDP processors were males and 35\%, were females. Again, the majority (70\%) of the extension agents were male while $30 \%$ of them were females. The low number of female cassava farmers may be because of land resource allocation prevailing in most communities. Ezedinma, et. al., (2007) opines that it is complicated for women to access land for agricultural purposes unless the husband or extended family/community and/or the community head agree to it. Also, the dominance of males as processors may not quite agree with Achem (2011) who noted that both males and females engaged in cassava processing activities, but with an overwhelming presence of females, where they accounted for 87 percent but is in conformity with the findings of Nweke (1994), who stated that women do all the microscale processing activities, while the men generally own the mechanized processing equipment, graters and grinders.

Data further show that the majority $(77.3 \%$ and $74.6 \%)$ of the participant and nonparticipant farmers were married. The data also reveal that $90 \%$ of CEDP processors, $70 \%$ non-CEDP processors and $95 \%$ of the extension agents were married. The finding agrees with the results of Okolo, Omoregbee and Alufohai (2016) who reported 
Creative commons User License: CC BY-NC-ND

Abstracted by: EBSCOhost, Electronic Journals Service (EJS), Google Scholar, Directory of Open Access Journals (DOAJ), Journal Seek, Scientific Commons,

Food and Agricultural Organization (FAO), CABI and Scopus
Journal of Agricultural Extension

Vol. 21 (1) February, 2017

ISSN(e): 24086851; ISSN(Print); 1119944X

http://journal.aesonnigeria.org

http://www.ajol.info/index.php/jae

Email: editorinchief@aesonnigeria.org

that most producers being married is an indication that production might be regarded as a domestic chore. Igben (1980) stated that marital status is one of the most important factors conditioning the level of production and productivity. It also implies that they would have access to cheap labour and probably an additional source of income and better decision making process (Eze and Madukwe, 1999). The educational level of participant farmers indicates that $34 \%$ of them completed their primary schools, while $12.4 \%$ had no formal education. On the other hand, $24.9 \%$ of non- participant farmers had no formal education. The data further show that only $5 \%$ of the CEDP processors and 15\% non-CEDP processors had no formal education. This implies that the majority of both the participant and non-participant farmers and processors had one form of formal education at different levels. According to World Bank report in Erhabor and Emokaro (2007), the output of an educated farmer is about $13 \%$ higher than that of the uneducated. This is because the literate farmer has the added advantage of knowing with promptings, the rules of application of production inputs in order to achieve optimal results. Table 2 also shows that the majority (59.8\%) of the participant farmers had a household size of 6-10 people with a mean (M) household size of approximately 6 people. Also, the majority $(47.1 \%)$ of the nonparticipant farmers had 1-5 people with a mean (M) household size of approximately 6 people too. It further reveals that the majority (75\%) of the CEDP processors and of non-CEDP processors (60\%) had 6-10 people, in their households. Mean (M) household size was 6 people. This implies that the participant and non-participant farmers and processors had a fairly large household sizes, which could supply farm labour. According to Sule, Oguwale and Atala (2002), household size has a great role to play in family labour provision in the agricultural sector. 
Creative commons User License: CC BY-NC-ND

Abstracted by: EBSCOhost, Electronic Journals Service (EJS), Google Scholar, Directory of Open Access Journals (DOAJ), Journal Seek, Scientific Commons,

Food and Agricultural Organization (FAO), CABI and Scopus
Journal of Agricultural Extension

Vol. 21 (1) February, 2017

ISSN(e): 24086851; ISSN(Print); 1119944X

http://journal.aesonnigeria.org

http://www.ajol.info/index.php/jae

Email: editorinchief@aesonnigeria.org

Table 2: Percentage distribution of respondents according to their socioeconomic characteristics

\begin{tabular}{|c|c|c|c|c|c|c|c|c|c|c|}
\hline \multirow[b]{2}{*}{ Variable } & \multicolumn{2}{|c|}{ CBF(n=97) } & \multicolumn{2}{|c|}{$\operatorname{NCF}(n=68)$} & \multicolumn{2}{|c|}{ EAs $(n=20)$} & \multicolumn{2}{|c|}{ CEDPP (20) } & \multicolumn{2}{|c|}{$\begin{array}{l}\text { NCEDPP } \\
\text { (20) }\end{array}$} \\
\hline & $\%$ & M & $\%$ & $\mathbf{M}$ & $\%$ & M & $\%$ & $\mathbf{M}$ & $\%$ & M \\
\hline \multicolumn{11}{|l|}{ Age (years) } \\
\hline $30-39$ & 12.4 & & 25.6 & & 5.0 & & 15.0 & & 25.0 & \\
\hline $40-49$ & 47.4 & & 41.2 & & 60.0 & & 45.0 & & 40.0 & \\
\hline $50-59$ & 29.9 & 47.9 & 28.8 & 45.0 & 30.0 & 47.4 & 25.0 & 47.5 & 30.0 & 44.2 \\
\hline $60-69$ & 10.3 & & 4.4 & & 5.0 & & 15.0 & & 5.0 & \\
\hline 70 and above & 0.0 & & 0.0 & & 0.0 & & 0.0 & & 0.0 & \\
\hline \multicolumn{11}{|l|}{ Sex } \\
\hline Male & 53.6 & & 52.9 & & 70.0 & & 65.0 & & 50.0 & \\
\hline Female & 46.4 & & 47.1 & & 30.0 & & 35.0 & & 50.0 & \\
\hline \multicolumn{11}{|l|}{ Marital status } \\
\hline Single & 7.2 & & 8.8 & & 0.0 & & 5.0 & & 20.0 & \\
\hline Married & 77.3 & & 74.6 & & 95.0 & & 90.0 & & 70.0 & \\
\hline Widow & 15.5 & & 11.8 & & 5.0 & & 5.0 & & 10.0 & \\
\hline Divorce & 0.0 & & 4.8 & & 0.0 & & 0.0 & & 0.0 & \\
\hline \multicolumn{11}{|l|}{ Educational level } \\
\hline No formal education & 12.4 & & 24.9 & & 0.0 & & 5.0 & & 15.0 & \\
\hline Primary school attempted & & & & & 0.0 & & 25.0 & & 35.0 & \\
\hline Primary school completed & 34.0 & & 32.4 & & 0.0 & & 30.0 & & 35.0 & \\
\hline $\begin{array}{l}\text { Secondary } \\
\text { attempted }\end{array}$ & 0.0 & 9.6 & 0.0 & & 0.0 & 14.5 & 30.0 & 10.8 & 5.0 & 8.9 \\
\hline $\begin{array}{l}\text { Secondary } \\
\text { completed }\end{array}$ & 30.9 & & 32.4 & & 25.0 & & 10.0 & & 10.0 & \\
\hline Tertiary Education & & & & & & & & & & \\
\hline $\begin{array}{l}\text { OND/NCE } \\
\text { HND/ First Degree }\end{array}$ & 18.6 & & 10.3 & & 60.0 & & 0.0 & & 0.0 & \\
\hline $\begin{array}{l}\text { Higher Degrees } \\
\text { Household size (number) }\end{array}$ & 4.1 & & 0.0 & & 15.0 & & 0.0 & & 0.0 & \\
\hline $1-5$ & 36.1 & & 47.1 & & & & 25.0 & & 40.0 & \\
\hline $6-10$ & 59.8 & 6.2 & 46.1 & 5.5 & & & 75.0 & 6.2 & 60.0 & 5.2 \\
\hline $11-15$ & 3.1 & & 4.2 & & & & & & & \\
\hline More than 20 & 1.0 & & 2.6 & & & & & & & \\
\hline
\end{tabular}

Note: $\mathbf{M}=$ Mean; CBFs: CEDP benefiting Farmers; NCFs: Non-CEDP farmers; EAs: Extension Agents. CEDPP: CEDP processors; NCEDPP: Non-CEDP Processors

\section{Adoption of CEDP Cassava Varieties and Value Adding Technologies by Farmers}

Table 3 reveals the adoption levels of CEDP cassava varieties and value adding technologies disseminated to participant cassava farmers and processors. The improved CEDP technologies were the use of the new cassava mosaic disease (CMD) resistant varieties, agronomic practices and technologies, new cassava processing innovations, and improved marketing. 
Creative commons User License: CC BY-NC-ND

Abstracted by: EBSCOhost, Electronic Journals Service (EJS), Google Scholar, Directory of Open Access Journals (DOAJ), Journal Seek, Scientific Commons,

Food and Agricultural Organization (FAO), CABI and Scopus
Journal of Agricultural Extension

Vol. 21 (1) February, 2017

ISSN(e): 24086851; ISSN(Print); 1119944X

http://journal.aesonnigeria.org

http://www.ajol.info/index.php/jae

Email: editorinchief@aesonnigeria.org

\section{CEDP Cassava CMD Disease Resistant Varieties}

The new cassava varieties, TMS 98/0581 (Akpu Ufie, Ochogi Mmanu) had the highest mean adoption score of 2.7 (Table 3). This was followed by TMS 419 (Akpuimi Anwuru, Onu-Oji) and TMS 98/0510 (Eleegota lgwe) that had mean adoption scores of 2.49 each, respectively. On the other hand, TMS 98/0505 (Nwanyi Ocha) had mean adoption score of 2.39 and TMS 97/2205 (Okoro Ocha, Odogwu) had mean adoption score of 2.18. Their grand mean score is 2.44 , with adoption index of 0.49 . This implies that the majority of the CEDP participant farmers were still at the interest level of the adoption process in the use of the new CMD cassava varieties disseminated to the project farmers by CEDP. Of these farmers, $49 \%$ were involved in this process. The below average adoption of these cassava varieties might be because, Government had no sustainability plan to maintain the tempo in which the project started by encouraging the farmers to continue the -Participatory Research and Extension Approaches (PREA) adopted by the CEDP. According to Agbamu (2006); Tarawali, Adedzwa, Ezedinma and Okechukwu (2007), PREA is to ensure the development of technologies together with farmers; farmer experimentation and evaluation, sharing of experiences and farmer to farmer innovation dissemination with extension workers as facilitators. Therefore, for farmers to adopt this innovation, adequate sustainable plan must have to be developed to push the adoption level.

\section{Agronomic Practices, Systems and Technologies}

Table 3 also shows that the CEDP participant farmers had the highest mean adoption score of 3.62 in timely planting (April-June) of cassava in the agronomic practices disseminated by the project. This was followed by methods of fertilizer application (band placement or ring method) which had mean adoption score of 3.52. The implication is that farmers were at the trial stage on the 5-point adoption scale for these two practices. This could be as a result of the farmers conducting the project on-farm trials (OFTs) in collaboration with researchers and extension agents. On the other hand, mean adoption scores for timely harvesting, use of herbicides to control weeds, recommended plant spacing for sole crop (1m by $1 \mathrm{~m})$, fertilization (8-12weeks) after planting were $3.44,3.19$ and 3.12 respectively. This means that farmers were on the 
Creative commons User License: CC BY-NC-ND

Abstracted by: EBSCOhost, Electronic Journals Service (EJS), Google Scholar, Directory of Open Access Journals (DOAJ), Journal Seek, Scientific Commons,

Food and Agricultural Organization (FAO), CABI and Scopus
Journal of Agricultural Extension

Vol. 21 (1) February, 2017

ISSN(e): 24086851; ISSN(Print); 1119944X

http://journal.aesonnigeria.org

http://www.ajol.info/index.php/jae

Email: editorinchief@aesonnigeria.org

evaluation stage in these agronomic practices. While the mean adoption score for use of insecticides to control pest and intercrop $(1 \mathrm{M}$ by $500 \mathrm{~cm})$ were 2.99 and 2.97 . The grand mean score of agronomic practices, systems and technologies disseminated to farmers were 3.27 with adoption index of 0.65 . This means that $65 \%$ of the participant farmers were involved in these various adoption process. The high adoption could be as a result of the active collaboration and participation of the farmers, extension agents/facilitators and researchers in the PREA.

\section{Cassava Processing Innovation}

Table 3 shows that the mean adoption score for cassava chips processing skills was 2.74. This was followed by starch extraction technique from cassava ( $\bar{x}=2.39$ ), odourless fufu production technique ( $\bar{x}=2.33$ ), technique for the production of high quality garri ( $\bar{x}=2.33$ ) and production of high quality cassava flour (HQCR) $(\bar{x}=2.30)$ technique. On the other hand, the mean adoption score for cassava root meal for broilers and layers production technique was 2.08 and technique for the processing of ethanol from cassava was 2.07.

The result reveals that virtually all the farmers were at the interest level on the 5-point adoption scale, except in cassava chips processing skills which were on evaluation stage. The grand mean score was 2.32 with an adoption index of 0.46 , which means that $46 \%$ of the farmers were involved in the adoption processes of the various cassava processing innovations disseminated to them. The below average adoption of these innovations might be because the cassava processing methods and technologies being disseminated by the CEDP were new to the farmers. This is supported by Oyebanji and Akwashiki (2003) that the majority of cassava roots are processed at the village level by a variety of micro-scale methods into many different products according to local customs and preferences.

\section{Improved Marketing}

Table 3, also shows that the mean adoption scores for exploring marketing channels for cassava products, using marketing infrastructure mapping and using market information for networking were 2.35, 2.22 and 2.17, respectively. The grand mean score was 2.25 and the adoption index was 0.45 . This implies that the farmers were still at the interest level. The below average adoption of these improved marketing 
Creative commons User License: CC BY-NC-ND

Abstracted by: EBSCOhost, Electronic Journals Service (EJS), Google Scholar, Directory of Open Access Journals (DOAJ), Journal Seek, Scientific Commons,

Food and Agricultural Organization (FAO), CABI and Scopus
Journal of Agricultural Extension

Vol. 21 (1) February, 2017

ISSN(e): 24086851; ISSN(Print); 1119944X

http://journal.aesonnigeria.org

http://www.ajol.info/index.php/jae

Email: editorinchief@aesonnigeria.org

techniques could be because farmers understand the traditional food oriented market more than the new emerging market for industrially processed cassava. This is in agreement with Knipscheer, Ezedinma, Kormawa and Asumugha (2007), who stated that the majority of the cassava grown in Nigeria is processed and sold through traditional market channels, which are well known but much less is known about the market structure for industrial cassava. 
Creative commons User License: CC BY-NC-ND

Abstracted by: EBSCOhost, Electronic Journals Service (EJS), Google Scholar, Directory of Open Access Journals (DOAJ), Journal Seek, Scientific Commons,

Food and Agricultural Organization (FAO), CABI and Scopus
Journal of Agricultural Extension

Vol. 21 (1) February, 2017

ISSN(e): 24086851; ISSN(Print); 1119944X

http://journal.aesonnigeria.org

http://www.ajol.info/index.php/jae

Email: editorinchief@aesonnigeria.org

Table 3: Farmers' adoption level of CEDP varieties and value adding technologies

\begin{tabular}{|c|c|c|c|}
\hline CEDP innovations & $\mathbf{M}$ & $\begin{array}{l}\text { Grand } \\
\text { Mean }\end{array}$ & $\begin{array}{c}\text { Adoption } \\
\text { index }\end{array}$ \\
\hline \multicolumn{4}{|l|}{ Use of CEDP CMD resistant varieties / Local names } \\
\hline TMS 419 (Akpu imi anwuru, onu-oji) & 2.49 & \multirow{6}{*}{2.44} & \multirow{8}{*}{0.49} \\
\hline TMS 97/2205 (Okoro-Ocha, Odogwu) & 2.18 & & \\
\hline TMS 98/0505 (Nwanyi Ocha) & 2.39 & & \\
\hline TMS 98/0510 (Ele-egota Igwe) & 2.49 & & \\
\hline TMS 98/0581 (Akpu ufie, Ochogi mmanu) & 2.67 & & \\
\hline \multicolumn{2}{|l|}{ Agronomic practices, systems and technologies } & & \\
\hline $\begin{array}{l}\text { Recommended plant spacing for } \\
\text { sole cropping ( } 1 \mathrm{~m} \times 1 \mathrm{~m})\end{array}$ & 3.19 & & \\
\hline Intercrop $(1 \mathrm{~m} \times 50 \mathrm{~cm})$ & 2.97 & & \\
\hline Timely planting (April - June) & 3.62 & & \multirow{6}{*}{0.65} \\
\hline Timely harvesting (10-12 months) & 3.44 & 3.27 & \\
\hline Fertilization (8-12 weeks) after planting & 3.12 & & \\
\hline Methods of Fertilizer application (band placement or ring method) & 3.52 & & \\
\hline Use of herbicides to control weeds & 3.27 & & \\
\hline Use of insecticides to control pest & 2.99 & & \\
\hline \multicolumn{3}{|l|}{ Cassava processing innovations } & \multirow{9}{*}{0.46} \\
\hline Technique for the production of high quality garri & 2.33 & \multirow{8}{*}{2.32} & \\
\hline Production of high quality cassava flour (HQCR) technique & 2.30 & & \\
\hline Odourless fufu production technique & 2.33 & & \\
\hline Cassava root meal for broilers and layers production technique & 2.08 & & \\
\hline Technique for the processing of ethanol from cassava & 2.07 & & \\
\hline Starch extraction technique from cassava & 2.39 & & \\
\hline Cassava chips processing skills & 2.74 & & \\
\hline \multirow{2}{*}{\multicolumn{4}{|c|}{$\begin{array}{l}\text { Others Specify please } \\
\text { Improved marketing }\end{array}$}} \\
\hline & & & \\
\hline Using market information for networking & 2.17 & \multirow{3}{*}{2.25} & \multirow{3}{*}{0.45} \\
\hline Exploring marketing channels for products & 2.35 & & \\
\hline Using marketing infrastructure mapping & 2.22 & & \\
\hline
\end{tabular}

\section{Problems Constraining Effective Adoption by Participant Farmers}

Analysis of the problems constraining the effective adoption of the project innovations by the participant farmers as presented in Table 4, shows that nonavailability of planting materials $(\bar{x}=3.45)$ untimely availability of CEDP cassava varieties (TMS 419, 97/2205, 98/0505, 98/0510 and TMS 98/058) ( $\bar{x}=3.40)$, menace of cattle destroying cassava farms ( $\bar{x}=3.33)$, high cost of labour $(\bar{x}=3.67)$, and high cost of agrochemicals $(\bar{x}=3.30)$, as major constraints. Other constraints include high cost of transportation $(\bar{x}=3.46)$, high cost of fertilizer $(\bar{x}=3.60)$, poor access to credit $(\bar{x}=3.66)$, high incidence of pest and diseases $(\bar{x}=3.06)$, lack of adequate technical knowledge in use of improved technologies $(\bar{x}=3.16)$, inadequate/poor extension contact $(\bar{x}=3.17)$, lack of adequate market to sell produce $(\bar{x}=3.16)$ and inappropriate processing equipment $(\bar{x}=3.17)$. Also participant farmers identified the following as 
Creative commons User License: CC BY-NC-ND

Abstracted by: EBSCOhost, Electronic Journals Service (EJS), Google Scholar, Directory of Open Access Journals (DOAJ), Journal Seek, Scientific Commons,

Food and Agricultural Organization (FAO), CABI and Scopus
Journal of Agricultural Extension

Vol. 21 (1) February, 2017

ISSN(e): 24086851; ISSN(Print); 1119944X

http://journal.aesonnigeria.org

http://www.ajol.info/index.php/iae

Email: editorinchief@aesonnigeria.org

problems: high cost of cassava cuttings ( $\bar{x}=2.76)$, lack of sufficient land $(\bar{x}=2.5)$, poor soil fertility $(\bar{x}=2.85)$ and poor knowledge of cassava processing techniques

$(\bar{x}=2.98)$ to have constrained them from adopting the innovations.

This implies that inadequate / unaffordability of improved production and technical supports to project farmers by CEDP constrained effective adoption of their technological innovations because they are small-holder cassava farmers. This is supported by Erhabor and Emokwo (2007) who stated that most cassava farmers' are small-holder farmers, resource-poor and are unable to afford the basic requirement for improved production of cassava such as improved cassava varieties, mechanized tillage implements, fertilizers, and agro-chemicals. Therefore, efforts should be intensified towards increased availability of these critical production inputs, for increased cassava production, if this is not done, it may inadvertently result in the collapse of the cassava industry which may result in loss of jobs mostly in rural areas thereby causing food insecurity.

\section{Table 4: Mean scores of problems constraining effective adoption of project} innovation by farmers

\begin{tabular}{|c|c|c|}
\hline Problems & $\mathbf{M}$ & S.D \\
\hline Non availably of planting materials & 3.45 & .685 \\
\hline $\begin{array}{l}\text { Untimely availability of CEDP cassava varieties } \\
\text { 98/0505. TMS } 98 / 0510 \text { and TMS 98/0581) }\end{array}$ & 3.40 & .811 \\
\hline Menace of cattle destroying cassava farms & 3.33 & .828 \\
\hline High cost of labour & 3.67 & .522 \\
\hline High cost agrochemicals & 3.30 & .885 \\
\hline High cost of transportation & 3.46 & .706 \\
\hline High cost of fertilizer & 3.60 & .585 \\
\hline Cost of cassava cuttings & 2.76 & .937 \\
\hline Poor access to credit & 3.66 & .724 \\
\hline Lack of sufficient land & 2.55 & .740 \\
\hline Poor soil fertility & 2.85 & .970 \\
\hline High incidence of pests and diseases & 3.06 & .822 \\
\hline Lack of adequate technical knowledge in use of improved technologies. & 3.18 & .877 \\
\hline Inadequate/ poor extension contact & 3.17 & .858 \\
\hline Poor fertility of the soil & 2.93 & .927 \\
\hline Lack of adequate market to sell produce & 3.16 & .808 \\
\hline Poor of knowledge of cassava processing techniques & 2.89 & .889 \\
\hline In appropriate processing equipment & 3.17 & .843 \\
\hline
\end{tabular}

The constraint variables were further subjected to factor analysis (varimax rotation) in order to isolate important factors necessary for policy consideration. Table 5 shows 
Creative commons User License: CC BY-NC-ND

Abstracted by: EBSCOhost, Electronic Journals Service (EJS), Google Scholar, Directory of Open Access Journals (DOAJ), Journal Seek, Scientific Commons,

Food and Agricultural Organization (FAO), CABI and Scopus
Journal of Agricultural Extension

Vol. 21 (1) February, 2017

ISSN(e): 24086851; ISSN(Print); 1119944X

http://journal.aesonnigeria.org

http://www.ajol.info/index.php/jae

Email: editorinchief@aesonnigeria.org

that four constraint factors were extracted based the clustering of items. These were named environmental factors, production cost factors, input factors and technical factors.

Under factor 1 (environmental factors), the specific constraint variables included lack of sufficient land (0.687), poor soil fertility (0.843) high incidence of pests and diseases (0.725), and lack of adequate market to sell produce (0.683). Items that loaded high under factor 2 (production cost factors) included high cost of labour (0.776), high cost of agrochemicals (0.688), high cost of transportation (0.799), and high cost of fertilizer (0.702). Specific issues with high loading under factor 3 (input factors) include nonavailability of cassava planting materials (0.850), untimely availability of CEDP cassava varieties (TMS 419, TMS 97/2205, TMS 98/0505, TMS 98/0510 and TMS 98/0581 (0.852) and cost of cassava cuttings (0.5770). The main problems constraining effective adoption as perceived by the participant farmers under factor 4 (technical factors) included poor access to credit (0.676), and lack of adequate technical knowledge in the use of improved technologies (0.668).

The implication of the findings is that almost all the problems enumerated were constraining effective adoption of CEDP innovations by the participant farmers and posed obstacles to the performance of the project. These problems had been factors constraining cassava production in Nigeria. Erhabor and Emakoro (2007) and Aisueni and Azaiki (2007) pointed out that land acquisition pattern through communal or inheritance process, makes cassava to be grown on fragmented land, thereby making mechanization difficult. They also observed that despite the fact that cassava thrives on marginal soils with marginal fertility, it still needs adequate fertilizations for increased productivity but unavailability and cost of fertilizers make this impossible. Also, the resource poor farmers were unable to afford basic production requirements for improved production of cassava, such as improved planting materials, agrochemicals, access to credit etc. 
Creative commons User License: CC BY-NC-ND

Abstracted by: EBSCOhost, Electronic Journals Service (EJS), Google Scholar, Directory of Open Access Journals (DOAJ), Journal Seek, Scientific Commons,

Food and Agricultural Organization (FAO), CABI and Scopus
Journal of Agricultural Extension

Vol. 21 (1) February, 2017

ISSN(e): 24086851; ISSN(Print); 1119944X

http://journal.aesonnigeria.org

http://www.ajol.info/index.php/iae

Email: editorinchief@aesonnigeria.org

\section{Table 5: Problems constraining effective adoption of project innovation by}

\section{farmers}

\begin{tabular}{|c|c|c|c|c|}
\hline \multirow{2}{*}{ Problems } & \multicolumn{4}{|c|}{ Component } \\
\hline & 1 & 2 & 3 & 4 \\
\hline Non availably of planting materials & .084 & .136 & .850 & -.032 \\
\hline $\begin{array}{l}\text { Untimely availability of CEDP cassava varieties (TMS 419, TMS } \\
97 / 2205 \text {, TMS } 98 / 0505 \text {, TMS } 98 / 0510 \text { and TMS 98/0581) }\end{array}$ & .285 & .144 & .852 & .032 \\
\hline Menace of cattle destroying cassava farms & 466 & .596 & 189 & -.310 \\
\hline High cost of labour & .148 & .776 & .094 & -.061 \\
\hline emicals & .203 & .688 & .046 & .256 \\
\hline ortation & .095 & .799 & .053 & .302 \\
\hline High c & .089 & .702 & .076 & .105 \\
\hline uttings & -.126 & .045 & .577 & .128 \\
\hline sedit & -.078 & .303 & -.251 & .676 \\
\hline Lack of sufficient land & .687 & .097 & .003 & .061 \\
\hline Poor & .843 & 211 & -.100 & .110 \\
\hline of pests and diseases & .725 & .032 & .230 & .152 \\
\hline Lack of adequate technical knowledge in use of improved technologies. & .339 & .092 & 179 & .668 \\
\hline Inadequate/ poor extension contact & .189 & -.051 & .541 & .600 \\
\hline Poor fertility of the soil & .842 & .170 & -.009 & .057 \\
\hline Lack of adeg & .683 & .237 & .115 & .253 \\
\hline Poor of knowledge of cassava processing techniques & .560 & .080 & .258 & .533 \\
\hline In appropriate processing equipment & .403 & .151 & .180 & .485 \\
\hline
\end{tabular}

Component 1: Environmental factors, Component 2: Production cost factors, Component 3: Input factors, Component 4: Technical factors

\section{Conclusion and Recommendations}

The adoption level of CEDP CMD-resistant varieties (TMS 419, TMS 97/2205), TMS 98/0505, TMS 98/0510 and TMS 98/0581), processing innovations and improved marketing innovations by the farmers were low. Farmers were however on the evaluation stage on agronomic practices and cassava technologies introduced by the CEDP. The majority of the CEDP processors were at evaluation stage on processing innovations and improved marketing innovations but were at interest stage on cassava value adding technologies. The major problems constraining effective adoption of project innovations by farmers were grouped into environment factor, production cost factors, input factors and technical factors. The majority of the cassava farmers still cultivate both the local and improve cassava varieties. Public and private extension agencies should be encouraged to continue the extension service delivery of the CEDP for greater proportion of cassava farmers to adopt the new varieties. 
Creative commons User License: CC BY-NC-ND

Abstracted by: EBSCOhost, Electronic Journals Service (EJS), Google Scholar, Directory of Open Access Journals (DOAJ), Journal Seek, Scientific Commons,

Food and Agricultural Organization (FAO), CABI and Scopus
Journal of Agricultural Extension

Vol. 21 (1) February, 2017

ISSN(e): 24086851; ISSN(Print); 1119944X

http://journal.aesonnigeria.org

http://www.aiol.info/index.php/iae

Email: editorinchief@aesonnigeria.org

\section{References}

Achem, B. A. (2011). Assessment of Constraints to Cassava Value-Added Enterprises in Kwara State, Nigeria. Journal of Agricultural Extension, 15(1), 124-134.

Adetunji,O. (2007). Restoring the glory of agriculture: Olusegun Obasanjo's presidential years 1999-2007, FMA \& WR. Abuja, Pesther Brands Ltd

Agbamu, J. U. (2006). Essentials of agricultural communication in Nigeria.Lagos: Malthouse Press Limited, 203.

Aisueni,N.O and Azaiki,S.S (2007). Production of cassava, In: Erhabor, P.O, Azaiki, S.S and Ingawa, S.A (eds.), Cassava the white gold, Benin city, Nigeria, Initiative Publication, PP 39-69.

ENADEP (1993). Enugu state agricultural development programme guide on cassava production, Enugu, SNAPP press, pp 2.

Erhabor, P.O; and Emokaro C.O (2007). Economic importance of cassava, in: Erhabor, P.O; Azaiki, S.S and Ingawa, S.A (eds.), Cassava the white gold, pp1-16, Benin City, Nigeria, Initiative publication.

Ezedinma, C., J., Lemchi, R., Okechukwu, F., Ogbe,M., Akoroda, L., Sanni, E., Okoro, P., Ilona,C., Okarta and Dixon, A.G.O..(2007). Status of Cassava Production in South baseline report 2004. IITA, Ibadan. Pp 41

Ezedinma, C.; Sanni, L.; Okechukwu, R. (2007) Socio economic studies on selected cassava markets in Nigeria, IITA, Ibadan, Nigeria.

Ezedinma, C.I (1991). The effect of population pressure and gender on farm labour use in the cassava producing zones of sub-Saharan Africa, African journal of root and tuber crops; 3(2) pp35.

Ezike, J.O (1998). Delineation of old and new Enugu state, Bulletin of lands and survey, Ministry of Works, Enugu.

Igben, M.S (1980). Socio- economic activity of workers in some selected Nigerian rural communities, implications for rural development in Nigeria. Paper presented at the centre conference, University of Benin, September $22^{\text {nd }}-25^{\text {th }}, 1980$.

Igben, M.S (1988) Farmers capability profiles. In: M.S. Igben (ed.) The Nigerian farmer and agricultural institution: An assessment NISER, Ibadan Nigeria. 67-92

Knipscheer, H., Ezedinma, C., Kormawa, P., Asumugha, G., Mankinde, K., Okechukwu, R., \& Dixon, A. (2007). Opportunities in the industrial cassava market in Nigeria. International Institute for Tropical Agriculture (IITA).

NFRA (2007). Statistics on agricultural production. National Food Reserve Agency, Nigeria Federal Ministry of Agriculture and Water Resource, Abuja, Nigeria.

NPC (2006). National Population Commission Census report, Abuja.

Nweke, F.I (1994). Processing potential for cassava production growth in Africa, Ibadan, Nigeria, IITA, pp47.

Okolo, C.C., Omoregbee, F.C., and Alufohai, G.O. (2016). Income generation from shea butter production by women in North Central States of Nigeria. Journal of Agricultural Extension. 20 (1) 27-38 
Creative commons User License: CC BY-NC-ND

Abstracted by: EBSCOhost, Electronic Journals Service (EJS), Google Scholar, Directory of Open Access Journals (DOAJ), Journal Seek, Scientific Commons,

Food and Agricultural Organization (FAO), CABI and Scopus
Journal of Agricultural Extension

Vol. 21 (1) February, 2017

ISSN(e): 24086851; ISSN(Print); 1119944X

http://journal.aesonnigeria.org

http://www.ajol.info/index.php/jae

Email: editorinchief@aesonnigeria.org

Oyebanji, O.O and Akwasiki, H.K (2003). Infrastructure development for enhanced cassava marketing, Paper presented at the workshop and cassava processing/post-harvest and marketing, 23-25 June, 2003, Port Harcourt Nigeria.

Rogers, E.M (1983). Diffusion of innovations, $4^{\text {th }}$ edition, New York. The Free press.

Sanni, L., Ezedinma, C., Okechukwu, R., Lemchi, J., Ogbe, F., Adoroda, M. ... \& Dixon, A. (2007). Cassava Postharvest Needs Assessment Survey in Nigeria: Synthesis Report. International Institute of Tropical Agriculture (IITA), Ibadan, Nigeria.

Sule, A.M, Oguwale, S.A. and Atala, T.K. (2002). Factors affecting adoption of fishing innovation among fishing entrepreneurs in Jabba lake communities. In: T.A Olowu (ed.) Journal of agricultural extension of Nigeria. 6(1) 48-60

Tarawali G., Adedzwa D.K. Ezedinma C., Okechukwu, R., Lum, A.F., Dixon, A.G.O., Akoroda, M., Ogbe, F., Lemechi J., Sanni L.O., Ilona P. and Okoro E. (2007). Community analysis of Ikot Etuk Udo, Akwa ibom state, Nigeria. ISBN 9781312831.55pp

Tarawali,G., Ayoola, J.B., Ezedinma, C, Okechukwu, R., Lum, A.F., Dixon A.G.O., Akoroda M., Ogbe F., Lemechi J. Sanni L.O., Ilona P. and Okoro, E. (2007). Community analysis of Asa North Abia state Nigeria, IITA, Ibadan, Nigeria. 